\title{
ELECTRONIC PUBLIC PROCUREMENT AS A TOOL OF REFORM IN SOUTH AFRICAN PUBLIC PROCUREMENT
}

\author{
Geoné Kramer
}

\section{(2016) 3:1 APPLJ 1}

\begin{abstract}
The practice of electronic public procurement has globally gained seeming popularity over the past decade. At present, however, the use of electronic methods of procurement is not as widely used on the African continent, including South Africa. The benefits of e-procurement have been recognised by the South African National Treasury and a review of the South African procurement system was conducted. A transitioning process to an electronic public procurement system was set in motion, which led to the establishment of the e-Tender Publication Portal and the Central Supplier Database for Government. The review did however not extend to the legal and regulatory framework governing public procurement. This poses major regulatory implications. This article consequently seeks to identify the regulatory implications of the current dual public procurement system, which is partly paper-based with some electronic features. This will be done by firstly giving an overview of the e-procurement technologies that have already been implemented in the South African public procurement system, followed by an analysis of the advantages and disadvantages of e-procurement. Lastly, recommendations will be proposed to ensure the successful reform of the South African public procurement system.
\end{abstract}

\section{http:/lappli.journals.ac.za}




\section{ELECTRONIC PUBLIC PROCUREMENT AS A TOOL OF REFORM IN SOUTH AFRICAN PUBLIC PROCUREMENT}

Geoné Kramer

LLB (Stellenbosch); LLM (Stellenbosch)

\section{Introduction}

On a global level, the practice of electronic public procurement has gained seeming popularity over the past decade. ${ }^{1}$ The innovation of electronic procurement ("e-procurement") in the area of public procurement is attributable to the emergence of new information and communication technologies ("ICTS"). ${ }^{2}$ The growth of the Internet and advances made in information technology has largely made this possible. ${ }^{3}$ Despite the increasing development and use of electronic public procurement technologies worldwide, it appears at present as though the use of electronic methods of procurement is not as widely used on the African continent. Beyond the use of websites to publish procurement notices, the most popular procurement procedures used by procuring entities remain the traditional paper-based procurement procedures, ${ }^{4}$ which are time-consuming and convoluted. ${ }^{5}$ The use of paper-based procurement procedures may be ascribed to the lack of infrastructure on the mainly underdeveloped continent, but even in South Africa, where infrastructure can be described as being relatively developed, eprocurement is not widely used in the public sector by procuring entities. ${ }^{6}$

Electronic public procurement is the process by which government acquires the goods, construction works or services needed for its operations from outside service providers (the outside service providers generally being the private sector) via electronic means, usually the Internet. ${ }^{7}$ In simple terms, electronic public procurement means that the process of procurement is generally conducted online. ${ }^{8}$ The goal of electronic public procurement is primarily to eliminate or minimise the direct human interaction in the procurement cycle between the suppliers bidding on government tender opportunities and the government procurement officials. ${ }^{9}$ This will help ensure the predictability and systematic treatment of

\footnotetext{
${ }^{1}$ Schoenherr \& Rao Tummala 2007:8 8.

2 Ware, Moss, Campos \& Noone 2007:295 318; Henriksen \& Mahnke 2005:85 86.

3 Schoenherr \& Rao Tummala 2007:9.

${ }^{4}$ Caborn \& Arrowsmith 2012:261 305.

${ }^{5}$ Ware, Moss, Campos \& Noone 2007:320.

6 Caborn \& Arrowsmith 2012:305.

7 Schoenherr \& Rao Tummala 2007:8; Oliveira \& Amorim 2001:43 43; De la Harpe 2015:1572 1572.

8 Kühn \& Sherman, 2014:28.

9 United Nations Office on Drugs and Crime, 2013:27; Kühn \& Sherman, 2014:19.
} 
tenders as well as reduce the opportunities that can give rise to bribery. ${ }^{10}$ It is the interaction between these two parties that usually results in corruption in public procurement. ${ }^{11}$ Besides reducing the chances for corrupt behaviour within the public procurement system, various other benefits can be realised by modernising the procurement process through the introduction of an electronic public procurement system. The benefits include better quality service delivery through a more efficient procurement system; economic growth due to the development of infrastructure; and for suppliers, the cost of doing business with the state substantially decreases, ${ }^{12}$ resulting in the achievement of substantial potential savings through electronic public procurement. ${ }^{13}$

In February of 2015, the then South African Minister of Finance, Nhlanhla Nene, in his Budget Speech, made mention of the fact that the current South African public procurement system is not perfect. This is attributable to frequent allegations of corruption and the inefficiency of the current public procurement system. In light of this, the National Treasury conducted a review of the procurement system in the public sector, and drawing on the views of Government, business and civil society, decided that the current system is in need of reform and that an effective public procurement system is needed to ensure efficiency and transparency in the procurement process. ${ }^{14}$ Since public procurement is internationally increasingly being driven by technology, possibilities in procurement have opened up that were not available in the past. ${ }^{15}$ The potential of electronic systems to increase the efficiency and effectiveness of government spending was recognised. ${ }^{16}$ The National Treasury consequently decided to take advantage of these possibilities presented by electronic systems and the potential efficiency gains that are likely to result from the appropriate implementation thereof. ${ }^{17}$ Consequently, as part of the process of reforming the current system, a transitioning process to an electronic public procurement system was set in motion. The Office of the Chief Procurement Officer ("OCPO"), with Kenneth Brown as the chief procurement officer, led the modernisation of the public procurement system. ${ }^{18}$ As part of a strategy to modernise the current archaic government tendering system, an electronic tender portal for Government, the e-Tender Publication Portal, was established, along with the Central Supplier Database for

\footnotetext{
10 UNCITRAL, 2014:26.

11 United Nations Office on Drugs and Crime, 2013:27.

12 National Treasury South Africa, 2015.

13 Schoenherr \& Rao Tummala 2007:9.

14 Minister of Finance South Africa 2015:16.

15 Campos, Pradhan \& Recanatini 2007:428 432.

16 National Treasury South Africa, 2016:6.

17 Panayiotou, Gayialis \& Tatsiopoulos 2004:79 79.

18 National Treasury 2016:5.
} 
Government ("CSD"), ${ }^{19}$ which is a single consolidated comprehensive supplier database for all spheres of Government. ${ }^{20}$

Through the introduction of electronic public procurement technologies in the current public procurement system, the National Treasury has taken the first steps towards transforming the South African public procurement system from a traditional paper-based one to an electronic one. An electronic public procurement system is the way forward for public procurement, considering the advantages it can achieve, namely to reduce both costs and opportunities for corruption, ${ }^{21}$ which is the two most prevalent advantages for South African public procurement. It should however be noted that the advantages of using ICT in public procurement can only be realised if systemic weaknesses or problems are addressed adequately. ${ }^{22}$

Since a public procurement reform has begun with the partial implementation of an electronic public procurement system, it appears at present as though South Africa has a dual public procurement system - partly paper-based with some electronic features. This, however, poses regulatory implications. To date, no amendments have been made to the legislation and regulations governing public procurement to accommodate the introduction of electronic public procurement technologies and to facilitate the process of reform. The only provision made for the introduction of electronic public procurement in the legal and regulatory framework, are in the form of circulars and instruction notes issued by the National Treasury. Although these are formal legal documents that form part of the legal and regulatory framework, it is only on an extremely low level. The purpose of the circulars and instruction notes are to inform the accounting officers of departments, constitutional institutions and the accounting authorities of public entities that the use of the CSD and e-Tender Publication Portal will become mandatory from the prescribed dates.

The minimal provision made for the regulation of e-procurement in the legal and regulatory framework leads to uncertainty regarding the procurement process, which can lead to greater problems, such as corruption. A comprehensive and supportive legal and regulatory framework is needed in order for e-procurement to achieve the desired results, such as increased competition, enhanced transparency, reduced administrative costs, improved government efficiency and reduced opportunities for corruption in public procurement. ${ }^{23}$ Only

\footnotetext{
19 Minister of Finance South Africa 2015:17.

20 National Treasury South Africa, 2015.

${ }^{21}$ National Treasury 2016:5.

22 Ware, Moss, Campos \& Noone 2007:319; Systemic weaknesses prevalent in South African public procurement include corruption, wastage of public funds and mismanagement of the public procurement system.

${ }^{23}$ Ware, Moss, Campos \& Noone 2007:318-319.
} 
once the legal and regulatory framework is in place and streamlined, can an electronic public procurement system be introduced to anchor the new laws and regulations. ${ }^{24}$

This article will examine the possibility of public procurement reform in South Africa by introducing electronic public procurement technologies to enable end-to-end e-procurement. This will be done by firstly giving an overview of the e-procurement technologies that have already been implemented in the South African public procurement system in order to modernise the procurement process, namely the e-Tender Publication Portal and the CSD. It will be followed by an analysis of the advantages of e-procurement and the most prevalent problems associated with the use of an electronic public procurement system. The process going forward will subsequently be addressed, which will include a discussion on how the South African government can build on the current electronic public procurement technologies to take e-procurement further. In addition, in order for a government procurement reform to be successful, regulatory reform is necessary, and this subject will consequently receive attention under this section. Detailed guidance is needed to support the South African government in introducing and operating an effective e-procurement system. For this reason, guidelines from the Asian Development Bank ("ADB") and the Guide to Enactment of the UNCITRAL Model Law on Public Procurement will be used to propose a course of action for Government. ${ }^{25}$ Guidelines from the ADB and UNCITRAL can be used in conjunction because both are members of the Multilateral Development Bank Working Group on electronic government procurement. ${ }^{26}$ This means that both have a similar methodology when it comes to formulating and implementing electronic government procurement solutions as part of a public procurement reform. ${ }^{27}$ The UNCITRAL Model Law Guide to Enactment is of particular importance because it provides a template for reforming regulatory systems on public procurement. ${ }^{28}$ It also offers a regulatory framework for all procurement. ${ }^{29}$ This degree of flexibility that the Model Law offers will make it easily adaptable to the South African procurement regime. ${ }^{30}$ Lastly, the article will conclude with some final remarks.

\footnotetext{
24320.

${ }^{25}$ UNCITRAL refers to the United Nations Commission on International Trade Law; UNCITRAL, 2014:26.

${ }^{26}$ Asian Development Bank, 2013:ix.

27 ix.

${ }^{28}$ Arrowsmith 2004:17 17.

2919.

3021.
} 


\section{E-procurement in South Africa}

Since 2015, a number of technological innovations have been phased into the current public procurement system in order to establish an electronic public procurement system. ${ }^{31}$ The decision by the National Treasury and the OCPO, which is a division of the National Treasury, to make the move to e-procurement is primarily driven by the need to eliminate corruption and to cut the wastage of public funds when the government is engaged in the activity of buying goods and services from suppliers. ${ }^{32}$

An estimated amount of R460 billion is spent yearly by all spheres of government procuring goods and services ranging from computers, vehicles, police uniforms, school textbooks, medical equipment and medication for hospitals, private security personnel and facilities managers to protect and maintain government buildings. ${ }^{33}$ However, of this amount, billions of rands are either being squandered or spent irregularly by state procuring entities. ${ }^{34}$ The 2014-15 Consolidated general report on national and provincial audit outcomes by the Auditor-General, Kimi Makwetu, revealed irregular, fruitless and wasteful, and unauthorised expenditure to the extent of R25,7 billion. ${ }^{35}$ The OCPO, through the development and implementation of an e-procurement platform, is looking to curb exactly this type of expenditure. ${ }^{36}$ Accordingly, this necessitated the development of the e-Tender Publication Portal and the CSD as part of an e-procurement platform to improve and modernise procurement in the public sector. ${ }^{37}$

What this section will continue to do is to give an overview of the current procuring technologies being used for government tendering, namely the e-Tender Publication Portal and the CSD. It is important to make mention of the fact that these technologies are merely entry technologies. The e-Tender Publication Portal is an online portal that publishes government notices, advertisements of bids and awards, ${ }^{38}$ while the CSD only digitalises supplier information. These technologies are a part of a fragmented and under-utilised system

\footnotetext{
31 National Treasury South Africa, 2016:6.

${ }^{32}$ Ntingi, 2014.

33 Ntingi, 2014.

${ }^{34}$ Ntingi, 2014.

35 Auditor-General South Africa, 2015:1, 22.

${ }^{36}$ Ntingi, 2014.

${ }^{37}$ Ntingi, 2014.

38 National Treasury South Africa 2015:1.
} 
since $45 \%$ of public procurement is still conducted manually. ${ }^{39}$ At this moment in time, the South African e-procurement platform has only managed to modernise the archaic South African public procurement system by making the form of communication between government procuring entities and potential suppliers electronic. There is as of yet no technologies in use by means of which the actual activity of procurement can be done electronically.

\section{1 e-Tender Publication Portal}

The e-Tender Publication Portal for Government is an initiative instituted by the OCPO to support fair, equitable, transparent, competitive and cost-effective procurement in an easy to access, single point of entry, technology driven facility. The portal attempts to improve opportunities for South African businesses by enabling them to identify and compete for government tender opportunities put out to bid. ${ }^{40}$

The e-Tender Publication Portal is a centralised web portal where all national, provincial and local government tender opportunities will be advertised and the bids that have been awarded published. ${ }^{41}$ This will mean that information on all tenders disclosed by public sector organisations, at all spheres of government, will be easily accessible through this portal, ${ }^{42}$ phasing out the publication of tender advertisements in newspapers and the government gazette. ${ }^{43}$ The introduction of an online portal where all government tender opportunities will be advertised greatly reduces the incidence of collusion. ${ }^{44}$ The portal will provide all potential suppliers with easy and transparent access to government tender opportunities and all of the relevant bid documents for a particular tender by publishing tender advertisements and the accompanying documentation online. ${ }^{45}$ This increased accessibility will allow suppliers to search and locate tender opportunities with minimal effort, ${ }^{46}$ providing them with the opportunity to supply goods and services to government institutions. ${ }^{47}$

This portal will additionally publish the list of tenderers, their respective prices as well as information related to the awards of all advertised competitive bids, ${ }^{48}$ including details of

\footnotetext{
39 National Treasury South Africa, 2016:6.

40 National Treasury South Africa, 2015.

41 South African Government News Agency, 2015; National Treasury South Africa, 2015; Asian

Development Bank, 2013:13.

42 National Treasury South Africa, 2015.

43 Minister of Finance South Africa 2015:17.

44 Ware, Moss, Campos \& Noone 2007:319.

45 National Treasury South Africa, 2016:7; Asian Development Bank, 2013:13.

46 National Treasury South Africa, 2016:7; Asian Development Bank, 2013:13.

47 National Treasury South Africa, 2015:2.

482.
} 
the successful bidders, and the price awarded. ${ }^{49}$ The scores of the rest of the bidders will also be made available on the portal. ${ }^{50}$ By disclosing this information, the e-Tender Publication Portal enhances access to information in ways that were not possible through traditional paper-based procurement procedures. ${ }^{51}$ The portal also enhances the efficiency and transparency of tender award procedures. Over time, the portal has the potential to lead to a reduction in corruption and the number of tender disputes involved with the award of a tender contract. $^{52}$

National and provincial departments in South Africa were required to publish all public sector tenders greater than R500 000 on the electronic tender portal from 1 April 2015. Municipalities were only required to place all tenders greater than R200 000 on the electronic tender portal from 1 July $2015 .{ }^{53}$ From these dates forward the portal will regularly carry all public sector tender notices, accompanied by official tender documents and relevant Terms of Reference or other description of functionality that may be applicable; the publication of corrigendum by procuring entities; the publication of Award notices and minimum information prescribed by the OCPO; comprehensive information on procurement rules and guidelines and search capability to identify different opportunities (such as commodity category, tender type, tender status, region and sector). ${ }^{54}$ The e-Tender Publication Portal accordingly enables prospective suppliers to retrieve all the relevant information on public sector tenders. ${ }^{55}$

This initiative holds many practical benefits for both businesses and Government alike. The e-Tender Publication Portal will simplify, standardise and automate the procurement process by providing a tool where South African businesses and Government can meet digitally. ${ }^{56}$ Since the portal provides a single point of entry for the publication of national, provincial and local government tenders, it will directly contribute to reduce the duplication, fragmentation and inefficiency of traditional government tender publications for government tender opportunities. ${ }^{57}$ Along with this, it will also reduce duplication costs and effort associated with traditional tender publications, ${ }^{58}$ which will contribute to the better coordination of the administration of tenders. ${ }^{59}$ The wide availability of relevant information through the portal will most likely lead to an increase in the number of participating bidders, which will

\footnotetext{
49 National Treasury South Africa, 2016:7.

50 7; National Treasury South Africa, 2015.

51 Oliveira \& Amorim 2001:46.

52 National Treasury South Africa, 2016:7.

53 Timm, 2015.

54 National Treasury South Africa, 2015.

55 Ware, Moss, Campos \& Noone 2007:320.

56 South African Government News Agency, 2015.

57 National Treasury South Africa, 2015.

58 National Treasury South Africa, 2015.

59 South African Government News Agency, 2015.
} 
improve competition for government business and improve accountability and transparency in relation to the award of government tenders by mitigating the risks of collusion and bid rigging. ${ }^{60}$ In addition, the e-Tender Publication Portal will allow the National Treasury to identify public sector officials doing business with the state, a practice that the government is seeking to outlaw. ${ }^{61}$

As previously mentioned, this portal holds practical benefits for South African businesses, but it is Small Medium and Micro Enterprises ("SMMEs") in particular that will benefit from these technological innovations on the public procurement front. The portal allows SMMEs to evaluate tenders in a manner that is transparent, and accordingly, bid on an equal basis, since it is no longer required to pay to see tenders. ${ }^{62}$ By providing free access to public sector tender opportunities through a single point of entry to view, search and identify government tender opportunities, the e-Tender Portal will make the procurement procedure more accessible to prospective SMMEs, which will consequently promote greater participation. ${ }^{63}$ This will also increase the level of effective competition between actual and potential suppliers. ${ }^{64}$ In the process, it will make it easier, more affordable and transparent for SMMEs to do work for the government. ${ }^{65}$

Not only is access to the portal free of charge to prospective suppliers, there is also no charge to contracting authorities who wants so make use of this service. The e-Tender Publication Portal is also freely available for use by the oversight bodies, media and the public, which will enhance greater transparency and accountability in the procurement process. ${ }^{66}$

\section{Central Supplier Database}

In the past, the process of registration and verification of supplier information has not been uniform and standardised for all organs of state. The National Treasury identified this as one of the processes that made it increasingly difficult for prospective suppliers to do business with the State. ${ }^{67}$ It is for this reason that the National Treasury decided to establish and administer

\footnotetext{
60 Ware, Moss, Campos \& Noone 2007:320; National Treasury South Africa, 2015.

61 Timm, 2015.

62 National Treasury 2015:56.

63 Caborn \& Arrowsmith 2012:306; National Treasury South Africa, 2015.

64 National Treasury 2015:56.

65 Timm, 2015; South African Government News Agency, 2015.

66 National Treasury South Africa, 2015.

67 National Treasury South Africa, 2016:1.
} 
the CSD. ${ }^{68}$ The CSD will link with the abovementioned e-Tender Publication Portal in order to establish an electronic public procurement system for procurement activities in South Africa. ${ }^{69}$

From 1 April 2016, the CSD maintains a single comprehensive and consolidated database of the information of organisations, institutions and individuals who can provide goods and services to national, provincial and local levels of government. ${ }^{70}$ All prospective suppliers that wish to do business with government must be registered on the database from 1 April 2016 for transactions with national and provincial government and their entities. From 1 July 2016, all suppliers who wish to do business with municipalities must be registered on the database. ${ }^{71}$ This will minimise duplication and fragmentation of supplier information across all spheres of government. ${ }^{72}$ Procuring organs of state in all spheres of government will accordingly be able to access this database to receive accurate, up-to-date, complete and verified information on prospective suppliers. ${ }^{73}$

Prospective suppliers interested in pursuing opportunities within the South African government will only be required to register once on the National Treasury's database when they do business with the state. ${ }^{74}$ Since the database will henceforth be the single source of supplier information, it will eliminate multiple registrations by prospective suppliers with each organ of state they intend doing business with. ${ }^{75}$ This will consequently reduce and eliminate duplication of supplier registration effort. ${ }^{76}$

New suppliers are encouraged to make use of the self-registration function on the CSD website. The registration process has been simplified and will significantly reduce the administrative burden for Government as well as business, especially SMMEs. ${ }^{77}$ This selfregistration application represents an expression of interest from the supplier to conduct business with the South African government. Upon submission of all supplier information, it will be assessed for inclusion on the CSD. ${ }^{78}$ The assessment for inclusion on the CSD functions as a prequalification stage seeing as suppliers who are interested in bidding on government contracts must electronically submit information and documents that are usually required during prequalification and that attest to their qualifications. ${ }^{79}$ Suppliers who are

\footnotetext{
68 National Treasury South Africa, 2015:1.

69 National Treasury South Africa, 2015.

70 National Treasury, 2015; South African Government News Agency, 2015.

71 National Treasury 2016:59.

72 National Treasury South Africa, 2015.

73 National Treasury, 2015.

74 Minister of Finance South Africa 2015:17.

75 National Treasury South Africa Central Supplier Database 2015:2.

76 National Treasury South Africa, 2015.

77 Minister of Finance South Africa 2015:17.

78 National Treasury, 2015.

79 Ware, Moss, Campos \& Noone 2007:315.
} 
currently registered on a supplier database of any organ of state will automatically be transferred to the CSD. ${ }^{80}$ Upon inclusion on the CSD, the information of all newly registered suppliers, as well as the information of the transferred suppliers, will be stored in the database. How the CSD should subsequently function is, when a supplier has submitted a bid on a government contract, the supplier's information should be retrieved. Once the winning bidder has been selected, its qualification to perform the contract, including the qualifications submitted for inclusion on the database, should be subjected to evaluation. In this regard, the CSD should be used as a part of a post-qualification stage. If the bidder does not pass this post-qualification stage, it should be declared disqualified, and the supplier with the next best bid should be selected for post-qualification. ${ }^{81}$

Another technological innovation that will reduce administrative tasks for public procurement practitioners is the verification functionality of key supplier information. ${ }^{82}$ The CSD will facilitate the verification of supplier information on behalf of all departments, constitutional institutions and public entities listed in Schedule 2 and 3 of the Public Finance Management Act 1 of 1999 ("PFMA"). ${ }^{83}$ The database will interface with the South African Revenue Service ("SARS") to automate the verification of tax clearance certificates of suppliers. ${ }^{84}$ It will also interface with the Companies and Intellectual Property Commission ("CIPC") to enable automated vetting of business registration and business ownership. Over time, five additional interfaces will be added to automate bank account and bank account holder verification; verification of non-CIPC-suppliers; Broad-Based Black Economic Empowerment ("B-BBEE") information; verification of supplier information with the register for tender defaulters; and database of restricted suppliers and government employee verification to identify public sector officials doing business with the state. ${ }^{85}$ For government procurement officials, the benefit of the CSD interfacing with other databases with information applicable to suppliers would be a significant reduction in compliance burden as well as eliminating the duplication of effort and cost of receiving, validating and maintaining supplier registration information. ${ }^{86}$ Moreover it will also avoid the discrepancies resulting from the verification process done by institutions. ${ }^{87}$

For suppliers, the introduction of the CSD has reduced the cost of doing business with government significantly seeing as suppliers no longer have to incur costs of acquiring the

\footnotetext{
80 National Treasury South Africa, 2015.

81 Ware, Moss, Campos \& Noone 2007:315.

82 National Treasury South Africa 2015:1.

$831-2$.

${ }^{84}$ National Treasury South Africa, 2016:7.

85 National Treasury South Africa, 2015.

${ }^{86}$ National Treasury South Africa, 2015.

87 National Treasury South Africa 2015:2.
} 
above-mentioned administrative documents. ${ }^{88}$ On the other hand this also resulted in a reduction of administrative effort when doing business with government because there is a reduction in tender documents required for submission when responding to a tender. ${ }^{89}$

\section{Advantages of electronic public procurement}

As previously mentioned, the need exists to modernise South Africa's public procurement system, which can be made possible through technological innovations, such as an electronic public procurement system, for example. Transitioning to an electronic public procurement system and automating the procurement process will reduce the administrative burden for government and businesses alike and accelerate the procurement process. Not only will the efficiency of government procurement be promoted, ${ }^{90}$ the monitoring of procurement patterns, contracts and prices will be improved. ${ }^{91}$ An electronic public procurement system may potentially be seen as a partial solution to challenges of weak capacity and corruption, challenges that the current South African public procurement system suffers from. ${ }^{92}$

This section will firstly discuss how automation of the procurement process through an electronic public procurement system can potentially reduce opportunities for corruption. Subsequently, another primary benefit that can result from the adoption of an electronic public procurement system will be discussed, namely the significant cost savings that can be generated for government. ${ }^{93}$ Increased transparency, which can also be achieved through electronic public procurement, will also receive some attention. There are also a number of expected advantages for suppliers. ${ }^{94}$ Lastly, the most important intangible advantage of eprocurement, namely the process improvement benefits, will be discussed. ${ }^{95}$ It is important to note that the before mentioned list of advantages identified for further discussion are by no means exhaustive. ${ }^{96}$

\footnotetext{
88 National Treasury South Africa, 2016:7.

89 7; National Treasury South Africa, 2015.

90 Liao, Wang \& Tserng 2002:731 731.

${ }^{91}$ National Treasury South Africa, 2015.

${ }^{92}$ Caborn \& Arrowsmith 2012:305.

93 Kühn \& Sherman, 2014:28.

94 Panayiotou, Gayialis \& Tatsiopoulos 2004:92.

9592.

${ }^{96}$ Asian Development Bank, 2013:16.
} 


\section{Corruption}

Globally, public procurement is the government activity that is most vulnerable to corruption. ${ }^{97}$ This is due to the complexity, the size of the financial flow it generates and the close interaction between the public and the private sectors. ${ }^{98}$ In South Africa, the government also faces a number of public procurement challenges, of which corruption can be considered as the most threatening. ${ }^{99}$ The single largest source of corruption in South Africa is the current paperbased procurement system, which is an archaic and inefficient system for conducting procurement. ${ }^{100}$

It is widely recognised that by replacing a paper-based procurement system with the introduction of an electronic public procurement system, can potentially lead to significant improvements in public procurement, such as transparency, efficiency and effectiveness. ${ }^{101}$ However, this being said, the use of an electronic public procurement system is not a standalone measure to prevent the problems of corruption in public procurement - it may potentially reduce the opportunities for corruption during all phases of the procurement process, but may not eradicate corruption in its entirety. ${ }^{102}$ Standardised procedures can be implemented through the use of an electronic public procurement system, which will ensure the predictability and systematic treatment of tenders. There will consequently be no space for manipulation through human intervention to override established protocols that can lead to opaque decisionmaking, which is frequently a result of the current paper-based public procurement system. ${ }^{103}$

Firstly, electronic public procurement increases and improves opportunities for potential suppliers, the public, civil society and the government itself to monitor procurement processes, ${ }^{104}$ seeing as it is easily accessible because the process is conducted online. ${ }^{105}$ This will make it possible for civil society in particular to gain access to information, monitor individual processes and facilitate citizen monitoring, in the process ensuring transparency in procurement. ${ }^{106}$

\footnotetext{
9710.

9810.

99 Ambe \& Badenhorst-Weiss 2012:242 242.

100 National Treasury South Africa, 2016:7.

${ }^{101}$ Asian Development Bank, 2013:10.

102 Kühn \& Sherman, 2014:28.

103 National Treasury 2016:59; Kühn \& Sherman, 2014:19.

104 28; Asian Development Bank, 2004:5.

105 Kühn \& Sherman, 2014:28.

10628.
} 
Electronic public procurement can increase the number of prospective suppliers, and accordingly, the amount of competition, because the procurement process is more accessible when and if the procurement process is conducted online. The centralisation of all the information related to the procurement process in a publically available online portal, such as the e-Tender Publication Portal, for instance, will significantly enhance transparency, which, over time, will lead to a reduction in corruption. ${ }^{107}$ The automated process of electronic public procurement will also limit the opportunities for corrupt activities during the procurement process and as a result, reduce the amount of discretion exercised by procurement officials and their personal contact with private sector representatives. ${ }^{108}$

\section{Cost savings}

One of the key measurable benefits of e-procurement is a reduction in costs. ${ }^{109}$ It follows that cost savings will be amongst the most prevalent benefits that the South African government can expect to achieve by transitioning from a traditional paper-based procurement system to an electronic public procurement system. It is the goal of the OCPO to reduce the cost of doing business with government, and eliminate waste and duplication, which is achievable through modernising the procurement system. ${ }^{110}$ From the perspective of the supplier, if the cost of doing business with the government can be reduced, it will most likely result in a reduction of the prices of goods and services procured. ${ }^{111}$ It is consequently the government as well as the suppliers that will benefit from savings in cost.

Several countries around the world have already adopted an e-procurement system to primarily cut down on costs and generate savings for the government. ${ }^{112}$ The Mexican eprocurement system, CompraNet, has reduced the Mexican government's administrative costs by $20 \%$. This is the result of the reduction in both paperwork and previously required face-to-face interaction. ${ }^{113}$ ChileCompra, the Chilean e-procurement system, has also led to a more cost-effective way of doing business for the government. ${ }^{114}$ ChileCompra has managed to save over $\$ 70$ million annually for the Chilean government through efficiency

\footnotetext{
107 28; National Treasury South Africa, 2016:7.

108 Kühn \& Sherman, 2014:28.

109 Asian Development Bank, 2013:16.

110 National Treasury 2016:58.

111 Asian Development Bank, 2004:5.

112 Ware, Moss, Campos \& Noone 2007:319.

113320.

114320.
} 
gains along with the decrease in the cost of procurement advertisements. ${ }^{115}$ Savings ranging from $10 \%$ to $45 \%$ have been reported from the use of electronic auctions ("e-auctions") in the United Kingdom, resulting in $£ 270$ million in savings for taxpayers. ${ }^{116}$ The World Bank estimates that the potential saving resulting from the use of an electronic public procurement system can range from $6 \%$ to $13 \% .{ }^{117}$

Cost savings are the result of the increased efficiency of electronic public procurement. Electronic public procurement can be used to standardise documents and make them easily accessible to suppliers, reduce man-power needs by automating steps in the procurement process such as bidder registration, price and data analysis, and it enables bids to be tracked, all of which reduces the time required for procurement. ${ }^{118}$ The recently implemented e-Tender Publication Portal and CSD performs the above-mentioned tasks and will accordingly result in cost savings for Government due to the increased efficiency with which procurement is being done.

With 95000 suppliers having registered on the CSD so far, the estimated cost savings for government is R350 million. ${ }^{119}$ The savings will result from eliminating duplication of registration of suppliers at different departments and entities. ${ }^{120}$ The Minister of Finance, Pravin Gordhan, announced in his 2016 Budget Speech that the e-Tender Publication Portal is expected to save the Government R25 billion a year over the next three years, out of a government procurement budget of about R500 billion a year. This is a significant saving. ${ }^{121}$

According to the National Treasury, since the inception of the e-Tender Publication Portal in 2015, there has already been a substantial reduction in advertising and administrative costs. ${ }^{122}$ It is projected that that the portal will save government R700 million a year alone on advertisement and printing costs. ${ }^{123}$ Furthermore, the e-Tender Publication Portal can achieve additional savings for Government through a national price-referencing system, which will help Government to improve the quality of spending by providing state institutions with data on the ranges within which the price of commonly used goods and services should fall. ${ }^{124}$

\footnotetext{
115320.

${ }^{116}$ Asian Development Bank, 2013:16.

117 Kühn \& Sherman, 2014:28.

11828.

119 National Treasury South Africa, 2016:7.

1207.

121 Minister of Finance South Africa 2016:15; Timm, 2016.

122 Timm, 2016.

123 National Treasury South Africa, 2016:7.

124 Timm, 2015.
} 


\section{Improved transparency}

A cardinal feature, on which all procurement systems are built, is transparency. It is apparent that whenever information is made publically available, transparency is improved. Improved transparency is exactly what an electronic public procurement system is able to achieve with $I C T$, because more focus is placed on making more and better information publically available on the Internet. ${ }^{125}$ For example, the e-Tender Publication Portal is able to achieve improved transparency through the publication of all government departments' (provincial and national) tender opportunities. Since the inception of the e-Tender Publication Portal in 2015, the site has published over 2500 tenders worth about R35 billion. ${ }^{126}$ Another feature of the portal that improves transparency is that all other relevant tender information disclosed by procuring organs of state is equally available to all prospective suppliers on the portal. ${ }^{127}$

E-procurement is also a transparency mechanism in the sense that it reduces the discretion of government procurement officials seeing as the processes are automated. This leads to improved confidence in the procurement system and the integrity thereof. ${ }^{128}$ If the electronic public procurement system is appropriately structured, it can also potentially improve the monitoring and reporting capabilities of government and thus oversight of the procurement process. ${ }^{129}$

Another example of how transparency can be enhanced through e-procurement is, seeing as tender notices and documents are digital, it improves their quality by ensuring the integrity of mandatory text and selected optional text, compliance with guidelines on specific requirements, and completeness. ${ }^{130}$

It is clear that increased transparency is a direct result of an electronic public procurement system, but many other benefits arising through e-procurement are derived from enhanced transparency. ${ }^{131}$ Transparency is also a tool that can be used to combat corruption, contribute to better governance, value for money and good-quality service delivery in this significant area of government activity. ${ }^{132}$

\footnotetext{
125 UNCITRAL, 2014:27.

126 National Treasury 2016:58.

127 Paterson \& Chaudhuri 2007:159 180.

128177.

129 Ware, Moss, Campos \& Noone 2007:319.

130 Paterson \& Chaudhuri 2007:180.

131 UNCITRAL, 2014:26.

132 National Treasury South Africa, 2015.
} 


\section{Advantages for suppliers}

Conducting the procurement process through paper-based procedures predominantly involves substantial efforts and costs for suppliers, and additionally, the paper-based procedures provide a number of potential sources of errors. ${ }^{133}$ It is accordingly submitted that shifting to an e-procurement system also holds a number of expected advantages for suppliers.

Firstly, reduced administration costs can result in cost savings for suppliers. The improvement in the process through the use of e-procurement results in minimised errors in supplying the goods and services and minimised errors in billing, faster payment procedures and less bureaucratic procedures. ${ }^{134}$ It is expected that SMMEs will benefit substantially from these advantages of e-procurement. SMMEs are thus encouraged to use the new procurement technologies seeing as it may lead to their advancement, ${ }^{135}$ which is an important object of the South African public procurement system. ${ }^{136}$

By electronically advertising government tender opportunities on the e-Tender Publication Portal, SMMEs that are located outside of large cities in more rural parts of the country, will now have increased access to tender opportunities. These SMMEs will be able to give and receive information and submit their bids online. ${ }^{137}$ Electronic advertising, which is a feature of an e-procurement system, is able to yield better market access as the market is now opened up to SMMEs located far away and that might not have otherwise participated in the process of supplying goods and services to government. The e-procurement system, through electronic advertising, accordingly makes the procuring activity and a wider variety of tender opportunities more accessible to SMMEs. ${ }^{138}$ This consequently leads to better participation and competition. ${ }^{139}$

\footnotetext{
133 Stalzer, 2015.

134 Panayiotou, Gayialis \& Tatsiopoulos 2004:92.

13592.

136 National Treasury South Africa, 2002.

137 UNCITRAL, 2014:26.

138 Panayiotou, Gayialis \& Tatsiopoulos 2004:92; UNCITRAL, 2014:26.

13926.
} 


\section{Intangible advantages}

An intangible advantage of e-procurement is the process improvement benefits that can be gained. Process improvement benefits include reduced paperwork through the automation of the procurement process, ${ }^{140}$ rendering the entire process almost paperless; ${ }^{141}$ decreased redundancy and less bureaucracy; standardisation of the procurement process across all levels of government, as well as standardisation of documentation; ensured compliance with procurement laws and regulations; and easier access to information (such as background information on new potential suppliers, related tenders and purchases of the same nature). ${ }^{142}$ This will expedite the process and reduce the chances for errors. ${ }^{143}$

\section{Problems associated with electronic public procurement}

E-procurement is not a perfect solution for all the problems associated with traditional methods of procurement. Similarly, e-procurement does not come without its own problems and it is not a panacea. ${ }^{144}$ Problems associated with e-procurement include challenges with regards to the technology required for the functioning of such a system and the technological capabilities of public institutions; ${ }^{145}$ the inexperience of government officials in operating an electronic public procurement system; the training of suppliers on how to use such an electronic public procurement system; the possible retrenchment of superfluous government procurement officials; and the expense of developing and implementing an electronic public procurement system may outweigh the potential advantages.

\footnotetext{
140 Panayiotou, Gayialis \& Tatsiopoulos 2004:92.

141 Roche 2001:56 58.

142 Panayiotou, Gayialis \& Tatsiopoulos 2004:92.

143 Roche 2001:58.

144 Kühn \& Sherman, 2014:28.

145 Henriksen \& Mahnke 2005:89.
} 


\section{Technology}

An e-procurement system requires that the procurement functions be moved to electronic and digital platforms. ${ }^{146}$ Inevitably, the extent to which individual States can effectively implement and use e-procurement depends on the presence of adequate digital and telecommunications infrastructure and technology to facilitate these electronic and digital platforms. ${ }^{147}$

Seeing as South Africa is a developing country, the implementation of an electronic public procurement system may pose some challenges, especially with regards to the technology required for the effective implementation and functioning of such a system. Firstly, obsolete or non-functional equipment will affect the ability of public procurement officials to do their job. ${ }^{148}$ It may also compromise the e-procurement system. To address this concern, all state departments need to be equipped with new computer equipment to ensure the implementation of an effective e-procurement system. This will however require a substantial capital investment. ${ }^{149}$ Secondly, an efficient electronic public procurement system, as well as electronic communication, which is an integral part thereof, is dependent on the improvement and construction of digital and telecommunications infrastructure. ${ }^{150}$ If Government is not able to invest in infrastructure due to budgetary constraints, it might be wise to get assistance from the private sector and foreign aid. ${ }^{151}$ Otherwise, without the necessary infrastructure required for procurement functions, the potential of e-procurement might not be realised. Thirdly, the functioning of an e-procurement system is dependent on fast and reliable Internet broadband services. ${ }^{152}$ The challenge facing the National Treasury presently is the lack of access to broadband outside of the main economic centres (such as in poorer parts of cities or in rural and underdeveloped regions of South Africa). ${ }^{153}$ In South Africa, Internet penetration as a percentage of the population is only $47 \%$. Internet penetration as a percentage of the population in other regions in the world is nearly $95 \%$, which is extremely high in comparison to South Africa. ${ }^{154}$

\footnotetext{
146 De la Harpe 2015:1588.

147 UNCITRAL, 2014:28.

148 Williams-Elegbe 2014:209 215.

149 MacManus 2002:5 16.

150 De la Harpe 2015:1588.

1511572.

152 De la Harpe 2015:1588.

153 Timm, 2015.

154 STANLIB, 2015.
} 
The lack of access to broadband is not only affecting the government, but also SMMEs based outside of the main economic centres. ${ }^{155}$ This is because government tender opportunities, which will from now on only be accessible through the e-Tender Publication Portal, will remain beyond their reach because without access to broadband, SMMEs cannot obtain access to the portal. This is consequently limiting their ability to participate in eprocurement.

Apart from the fact that South Africa has been slow in improving access to broadband, in areas that do have access, an effective electronic public procurement system might be hampered by an unstable Internet connection or slow connection speeds. ${ }^{156}$ The global average connection speed is 6.3 megabits per second ("Mbps"), while the global average peak connection speed is 34.7 Mbps. ${ }^{157}$ South Africa has an average connection speed of 6.5 Mbps. ${ }^{158}$ In terms of world rankings, it manages to secure South Africa the $73^{\text {rd }}$ fastest average connection speed in the world. In the first quarter of 2016, South Africa's peak connection speed was measured at $30.1 \mathrm{Mbps}$, securing a world ranking of $87^{\text {th }}$ highest peak connection speed. ${ }^{159}$ As regards to the global averages, South Africa fares fairly well. When compared to the world leaders, this is however not the case. South Korea is the country with the highest average connection speed, with $29.0 \mathrm{Mbps}$, while the number one ranking for highest peak connection speed belongs to Singapore, with 146.9 Mbps. ${ }^{160}$ Moreover, what remains the biggest obstacle in terms of Internet access is the high usage costs in South Africa. South Africa is among the few developing countries that have a high-cost/low-speed Internet ratio. ${ }^{161}$ What this means is that in South Africa a high price is paid for a slow Internet service. ${ }^{162}$ The conclusion that can be drawn from this is, access to affordable and fast Internet is vital for the successful adoption of an electronic public procurement system; otherwise, it will negate any advantages that such a system might hold for Government and businesses. ${ }^{163}$

Another problem, unique to South Africa, that has the potential effect of disrupting the functioning of the technology needed for e-procurement, is the unreliable electricity supply. ${ }^{164}$ In 2015, Eskom, the state power utility, enforced load-shedding. ${ }^{165}$ This was due to a greater

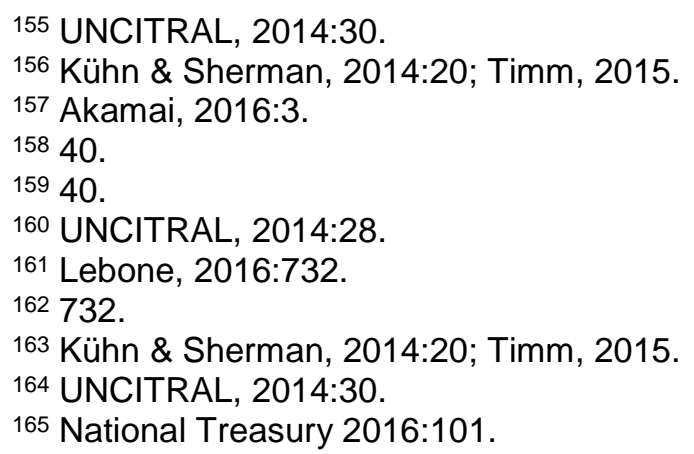


demand on the system than available supply. ${ }^{166}$ Although Eskom has since then been working to stabilise and augment electricity supply to avoid the likelihood of load-shedding in the future, ${ }^{167}$ interrupted electricity supply poses a big risk to the effective functioning of an eprocurement system and the ability of public procurement officials to do their job. ${ }^{168}$ In order for the procurement function to be moved to electronic and digital platforms, government should ensure that basic infrastructure, such as electricity supply, is dependable. ${ }^{169}$

In conclusion, the technological obstacles posed by the unavailability of the relevant technologies, infrastructure deficiencies, limited access to broadband and an unreliable power supply due to load-shedding, might hinder the effective implementation of an e-procurement system in the South African context. ${ }^{170}$ It in fact has the potential to undermine the whole process of reform of the public procurement system. ${ }^{171}$ However, if Government is able to overcome these obstacles by properly addressing the technological challenges, public procurement, through an e-procurement system, has the potential to become one of the most important drivers of economic development in South Africa. ${ }^{172}$

\section{Inexperienced government procurement officials}

South Africa does not have robust computer literacy. ${ }^{173}$ This means that if computer illiterate government officials do not receive adequate training in operating an electronic public procurement system, it will render the many potential advantages of such a system meaningless. ${ }^{174}$ It is important to place focus on the adequate training of procurement officials in operating an electronic public procurement system in order to take advantage of the new system. ${ }^{175} \mathrm{~A}$ substantial financial investment may be required to train government officials on how the system functions.

\footnotetext{
166 Eskom, 2015.

167 National Treasury 2016:101.

168 Williams-Elegbe 2014:215.

169215.

170 UNCITRAL, 2014:30.

171 Williams-Elegbe 2014:215.

172 De la Harpe 2015:1572.

173 Kühn \& Sherman, 2014:20

174 Ware, Moss, Campos \& Noone 2007:319.

175 Panayiotou, Gayialis \& Tatsiopoulos 2004:85; Timm, 2015.
} 
An alternative measure that can be taken to address the problem of inexperienced government procurement officials is, alongside with the introduction of an electronic public procurement system, to train a professional core that will be specialised in e-procurement. ${ }^{176}$

\section{Supplier training and support}

It is not only the government procurement officials in need of training, but also the prospective suppliers who will be using the electronic public procurement system who need adequate training. An e-procurement system will only be successful if suppliers actively participate in the online procurement activity. ${ }^{177}$ The problem with this is that suppliers do not necessarily know how to use new telecommunication platforms and software. ${ }^{178}$ This can also be exacerbated by the fact that ICTs are not readily available to suppliers. ${ }^{179}$

For example, the e-Tender Publication Portal will place an additional burden on the National Treasury to take the necessary steps to ensure that small enterprises, both in rural and urban parts of the country, receive sufficient support to access the new portal. Support can take on the form of training workshops held throughout the country where free training and advice is offered. In the case of the e-Tender Publication Portal, suppliers should firstly be introduced to the portal and how to register on the portal. Secondly, suppliers should be taken through the steps of how to use the portal to tender for government contracts. The same applies to the CSD. All institutions must provide CSD registration support to prospective suppliers who are unable to self-register on the database or may require assistance with registration. ${ }^{180}$

Concerning the CSD, the problem of training and support has to a large extent been addressed. Training and support requirements can be forwarded to an e-mail address dedicated to this specific purpose. Telephonic support is also available by contacting the OCPO call centre. Notwithstanding these two support avenues, the National Treasury is committed to facilitate access to the system and to provide training. ${ }^{181}$

\footnotetext{
176 Timm, 2015.

177 16 ${ }^{\text {th }}$ Bled Electronic Commerce Conference: eTransformation, 2005:33.

17833.

17933.

180 National Treasury South Africa 2015:3.

181 National Treasury South Africa 2016:4.
} 
The training of suppliers will enable them to make use of e-procurement, but it might place a financial and administrative burden on the National Treasury. ${ }^{182}$ It can also be time consuming and possibly delay the introduction of an e-procurement system. ${ }^{183}$

\section{Retrenchment of government procurement officials}

By using an electronic public procurement system, the procurement process becomes automated by the use of ICTs. The system is accordingly much more efficient in relation to when the process was conducted manually through procurement staff. The reason being that the transaction time of a bid cycle is significantly reduced with an e-procurement system. ${ }^{184}$ E-procurement could directly lead to procurement cost savings in terms of human resources expenditure seeing as the automation of the procurement process will significantly reduce the number of procurement staff needed. ${ }^{185}$ This may however lead to the retrenchment of superfluous staff because they are simply not needed anymore due to the automation of the process.

\section{The expense of a new public procurement system}

The successful implementation of a fully integrated electronic public procurement system and linking it with other systems may take many years. ${ }^{186}$ This means that it may take a number of years before the full benefits of such a system will be realised. ${ }^{187}$

A certified ready-to-use system will have to be preceded by a pilot implementation of the new system to ensure the system is duly tested. ${ }^{188}$ The implementation of the new system will also most likely occur in a staged manner, which will prolong the time it will take before the system will be operational. ${ }^{189}$ This will require a significant financial investment seeing as

\footnotetext{
182 Timm, 2015.

183 16 th $^{\text {th }}$ Bled Electronic Commerce Conference: eTransformation, 2005:33.

184 Ware, Moss, Campos \& Noone 2007:320.

185 Henriksen \& Mahnke 2005:92.

186 UNCITRAL, 2014:26.

18727.

188 Jooste \& Van Schoor 2003:1 9.

189 UNCITRAL, 2014:27.
} 
e-procurement technology is advanced and costly. ${ }^{190}$ Although, as was mentioned earlier, cost savings can be one of the most significant advantages of transitioning to an e-procurement system, the costs involved in implementing and operating such a system can be financially crippling for a state. A cost-benefit analysis during the planning phases of a reform will be crucial in order to determine whether an e-procurement system will be viable in the long run.

Since the financial burden of creating and implementing an e-procurement system will lie squarely on the state, a related issue is whether the suppliers, by using the proprietary information technology systems and specialist software for e-procurement, will be charged a fee. ${ }^{191}$ The use of the current e-procurement technologies, namely the CSD and the e-Tender Publication Portal, are free of charge. Market access will also be enhanced if potential suppliers are allowed to continue participating without charge ${ }^{192}$ Although the charging of fees for the use of the system is discouraged, ${ }^{193}$ the National Treasury will be placed under significant pressure to recover the cost of a new e-procurement system (which includes the cost of managing the system). The only viable option may be to start charging suppliers a fee for the use of the system. ${ }^{194}$ In the case where fees are levied, such fees must be transparent, justified, reasonable and proportionate. ${ }^{195}$ It should also not discriminate or restrict access to government tender opportunities. ${ }^{196}$ Such fees should therefore be disclosed in a clear manner by the procuring entity in the invitation to bid. ${ }^{197}$

By levying charges, the financial burden is shifted from government to suppliers, which may possibly decrease participation and competition. ${ }^{198}$ An alternative to this potential problem may be to consider using off-the-shelf or open-source software or other nonproprietary information technology in the e-procurement system, eliminating charging the users of the system a fee. ${ }^{199}$

\footnotetext{
190 Jooste \& Van Schoor 2003:9.

191 UNCITRAL, 2014:31.

19231.

193242.

19431.

195242.

196242.

197242.

19830.

199 UNCITRAL, 2014:31.
} 
Furthermore, if incompetent government officials poorly manage the electronic public procurement system, or if the system is dependent on a sub-par online platform, eprocurement can in fact enhance corruption risks associated with procurement. ${ }^{200}$

Having regard to all of the potential expenses that the adoption and operation of a new electronic public procurement system may hold, it is of the utmost importance that any state, South Africa included, that is exploring the possibility of reforming their current public procurement system, should be mindful of both the potential advantages and problems of the reform process in order to determine whether reform will in actual fact be a feasible undertaking at any given point in time.

\section{$5 \quad$ Going forward}

A number of issues currently stand in the way, preventing the South African government from achieving an efficient and cost-effective public procurement system. ${ }^{201}$ This section will firstly address how the OCPO can go about taking the next step towards implementing the reform of the current public procurement system. Secondly, the need for legal and regulatory reform to deal with the diversity of issues associated with the transition to an electronic public procurement system will be discussed. ${ }^{202}$

Lastly, seeing as no one-size-fits-all solution for formulating and implementing an electronic public procurement solution exist, ${ }^{203}$ guidelines from the ADB and the Guide to Enactment of the UNCITRAL Model Law on Public Procurement will be used to propose an electronic public procurement system for the South African government. These guidelines are not specific to any particular jurisdiction and can be used as an electronic government procurement strategy for any jurisdiction interested in pursuing the implementation of an electronic government procurement system. ${ }^{204}$ The ADB provides an up-to-date summarised handbook of internationally recognised best practices in formulating and implementing electronic public procurement solutions, ${ }^{205}$ rendering it a useful guide for the South African public procurement system. Moreover, the UNCITRAL Model Law Guide to Enactment can add particular value to the process of reform in developing and transitioning countries. ${ }^{206}$

\footnotetext{
200 Kühn \& Sherman, 2014:28.

201 National Treasury South Africa, 2016:8.

202 Oliveira \& Amorim 2001:46.

203 Asian Development Bank, 2013:ix.

204 ix.

205 ix.

${ }^{206}$ Arrowsmith 2004:18.
} 
South Africa, as a developing country, is currently involved in transitioning its public procurement system and can benefit greatly from the model rules of the UNCITRAL Law. ${ }^{207}$ Seeing as the Model Law offers sound solutions and is well drafted, ${ }^{208}$ the government can merely copy these model rules as they find it appropriate and applicable to the South African procurement regime. ${ }^{209}$ The Model Law as a guide to 'best practice' can encourage sound policies, reduce the resources needed for implementation and potentially minimise errors or other possible defects. ${ }^{210}$ All of these reasons mentioned above make the ADB guidelines and the UNCITRAL Model Law valuable and helpful instruments in the area of electronic public procurement. ${ }^{211}$

\section{How to take the South African electronic public procurement system further}

The only technologies that currently make up the South African electronic public procurement system are the e-Tender Publication Portal and the CSD. These however, are only the entry technologies needed for e-procurement. The functions of the e-Tender Publication Portal include the advertisement of government tender opportunities and tender related information, such as the announcement of contract awards and prices, as well as the announcement of bid prices and evaluation results. Furthermore, through the portal, tender documents will be accessible online for downloading. ${ }^{212}$ Through the CSD, by registering once on the database, a supplier directly expresses their interest to do business with the government and by interfacing with other systems, the CSD will be able to determine the eligibility of suppliers. ${ }^{213}$

Reform should not only involve digitising existing procurement practices. If paper communications are merely replaced with e-mails, Internet-based communications and advertising government tender opportunities on a website such as the e-Tender Publication Portal, many of the previously mentioned advantages of an e-procurement system will not materialise. ${ }^{214}$ Furthermore, the weaknesses of the current procurement system will simply be transferred to its new, digital equivalent. ${ }^{215}$

\footnotetext{
20719

20820.

20919.

21019.

211 23-24.

212 Paterson \& Chaudhuri 2007:180.

213180.

214 UNCITRAL, 2014:28.

21528.
} 
The emerging approach in procurement is to completely restructure and reform the process around the technical capabilities of new technologies instead of applying technology to existing processes. ${ }^{216}$ This will require that the traditional procurement processes be abolished in its entirety. ${ }^{217}$ An overhaul of an entire procurement system may involve a significant investment, but it is an opportunity to reform the entire procurement process, to enhance governance standards and to utilise ICT for this purpose. ${ }^{218}$ With these benefits in mind, the approach the National Treasury is suggested to take in order to reform the South African public procurement system is to abolish the traditional paper-based procurement system in its entirety. The current system in operation should completely be restructured and reformed around e-procurement technologies, instead of simply adding technologies to the current system, which is not ideal. This is because the scope for reform and the possibilities are so much greater when a system can be built from the ground up instead of working within the confines of an already established, somewhat lacking, system.

Reform should entail the design, development and implementation of an entirely new electronic public procurement system that provides a suitable and reliable platform for procurement to be done electronically. This means a system that has the functionality for suppliers to submit bid documents directly online to enable full (end-to-end) e-procurement, which means that the entire procurement activity is automated and done online.

An end-to-end e-procurement solution comprises of three main areas, namely electronic tendering ("e-tendering"), electronic purchasing ("e-purchasing") and electronic contract management ("e-contract management"). E-tendering is a solution that will electronically enhance the processes of public tendering for the procurement of specialised works, goods and consulting services of a high value and low volume. ${ }^{219}$ To get e-tendering off the ground is fairly simple. All that is needed is for a government agency to issue a series of procurement documents containing its specific procurement requirements. The benefit of introducing e-tendering is that it can be phased in gradually and it provides wide exposure to electronic public procurement at a low cost. ${ }^{220}$ E-purchasing is a solution that is designed to electronically facilitate the procurement of standard goods and services of a low value and high volume. ${ }^{221}$ The essential components needed for the implementation of an e-purchasing system tend to be complex and therefore require substantial system development. ${ }^{222}$

${ }^{216}$ Campos, Pradhan \& Recanatini 2007:432.

217432.

218 UNCITRAL, 2014:28.

219 Asian Development Bank, 2004:6.

2206.

2216.

2226. 
Electronic catalogues are used as part of an e-purchasing system. ${ }^{223}$ These catalogues are sometimes merely electronic versions of traditional catalogues. ${ }^{224}$ The process entails the online publication of goods and services offered by the suppliers from which government procurement officials can electronically select what needs to be procured. Once selected, it is ordered and the goods or services will be received, upon which the purchasing side will tender payment. ${ }^{225}$ The use of electronic catalogues can reduce costs, reduce unorthodox purchasing and assist public procurement entities to monitor expenditure. ${ }^{226} \mathrm{E}$-contract management is the electronic enhancement of the management of receivables, payments, contract settlements, contract variations, bid securities and auditing and control activities. ${ }^{227}$

Once an e-procurement solution comprises of all three electronic procurement processes, e-tendering, e-purchasing and e-contract management, an end-to-end eprocurement system will be established. When it comes to transitioning to an end-to-end eprocurement system, it is suggested that a gradual approach should be taken when implementing the abovementioned electronic procurement processes. Implementation should start with the least complex process, which is e-tendering, and the more complex process, namely e-purchasing, should only be implemented last. ${ }^{228}$ The reform of the South African public procurement system that started with the implementation of the e-Tender Publication Portal and the CSD was in line with this approach. In accordance with taking a gradual approach to establishing an end-to-end e-procurement system, the next step in the process of reform should be to give due consideration to the process of e-purchasing. e-Purchasing will entail designing and implementing a procurement solution that will facilitate the procurement of goods and services online.

Seeing as a potential e-procurement solution can comprise of three different processes that has to be established in their own right to create an end-to-end e-procurement system, it becomes important to properly facilitate such reform in order to ensure the success of the end product. Thus, in order to facilitate the public procurement reform and the effective application of electronic public procurement technologies, all the major role-players that are involved in public procurement in South Africa, namely the Minister of Finance, the National Treasury and the OCPO, need to formulate an electronic public procurement reform agenda. The OCPO will be the main driving force behind such an agenda to reform the public procurement system seeing as the responsibility of designing and implementing effective ICTs needed for public

\footnotetext{
2236.

224 Arrowsmith 2004:39.

225 Asian Development Bank, 2004:6.

226 Arrowsmith 2004:39.

227 Asian Development Bank, 2004:7. 2288.
} 
procurement rests on the OCPO. ${ }^{229}$ A proposed reform agenda will be discussed in some more detail in section 5.3 below.

When considering reform of the current public procurement system, it is important to take careful consideration of the South African legislative framework and the scope for eprocurement. ${ }^{230}$ The General Procurement Guidelines issued by the Government of the Republic of South Africa, sets out certain core principles. These principles must be diligently pursued "when an organ of state in the national, provincial or local sphere of government, or any other institution identified in national legislation, contracts for goods or services", namely value for money; open and effective competition; ethics and fair dealing; accountability and reporting and equity. ${ }^{231}$ In South Africa, the legal regulation of public procurement is relatively unique - it is one of very few states that afford public procurement constitutional status. ${ }^{232}$ These principles are enshrined in section 217(1) of the Constitution of the Republic of South Africa, 1996 ("Constitution"). Whichever approach to reform is chosen and whatever electronic public procurement system is selected, it is essential that these five principles, referred to as the "Five Pillars of Procurement", need to be earnestly pursued in order to achieve a public procurement system that is proper and successful. ${ }^{233}$

\section{The need for regulatory reform}

Concerning the introduction of an e-procurement system, the development of an efficient eprocurement system as well as the effective implementation thereof depends on the adequacy of the applicable law permitting and regulating e-commerce. ${ }^{234}$ The legal and regulatory framework should ensure that e-procurement is lawful and that it can subsequently guarantee the non-discriminatory and transparent awarding of government contracts. ${ }^{235}$

\footnotetext{
229 Williams-Elegbe 2014:215.

230 Bolton 2008:1 2.

231 National Treasury South Africa, 2002; Section 217(1) of the Constitution of the Republic of South Africa, 1996 (Constitution).

232 Bolton 2008:2.

233 National Treasury South Africa, 2002; Ntingi, 2014.

234 UNCITRAL, 2014:28; 16 ${ }^{\text {th }}$ Bled Electronic Commerce Conference: eTransformation, 2005:34. 23534.
} 


\section{Reform in general}

In order to achieve the potential benefits of an e-procurement system, such as improved performance, increased transparency and reduced opportunities for corruption, systemic weaknesses and problems need to be addressed adequately to provide the necessary support for an e-procurement system. ${ }^{236}$ This means that the relevant laws, regulations and policies need to be established and implemented fully in terms of a legal and regulatory framework to accomplish the desirable economic as well as social goals, ${ }^{237}$ which is an intrinsic part of the South African public procurement regime.

In 2004, the South African public procurement system saw a disbandment of the National Tender Board. This led to procurement being devolved to a fragmented system of over 600 government entities that put out government tenders. ${ }^{238}$ The current regulatory framework governing public procurement was written to regulate such a devolved and fragmented system. The idea behind e-procurement is to shift procurement activities from a decentralised system toward a transparent centralised system. ${ }^{239}$ In accordance with the transitioning of the current devolved and paper-based public procurement system to an electronic public procurement system with the introduction of the e-Tender Publication Portal and the CSD in the public sector, the regulatory framework, including legislation and regulations, needs to be amended to make provision for this new centralised electronic public procurement system, the introduction of ICT and to modernise the procurement rules. ${ }^{240}$

Reform of the current regulatory framework governing the South African public procurement system, such as the laws and regulations, are accordingly necessary to consolidate the fragmented legal and regulatory landscape of the current system as well as to accommodate the introduction of ICT. This will have the effect of aligning the legal and regulatory landscape with the practices in procurement. ${ }^{241}$ The reform can take place in two proposed ways. Firstly, the existing legal and regulatory framework can be amended by inserting provisions relating to e-procurement into the current laws and regulations. Eprocurement will accordingly be operationalised within the existing framework of legislation and regulation. ${ }^{242}$ The advantage of working within the existing legal and regulatory framework is that it is a much quicker and easier process than bringing about legal change across-the-

\footnotetext{
236 UNCITRAL, 2014:28; Ware, Moss, Campos \& Noone 2007:319.

237 Panayiotou, Gayialis \& Tatsiopoulos 2004:95.

238 Timm, 2015.

239 Henriksen \& Mahnke 2005:96.

240 National Treasury 2016:59.

24159.

242 Bolton 2008:1.
} 
board. ${ }^{243}$ Alternatively, the entire regulatory framework could be redrafted in the form of a new Public Procurement Bill, ${ }^{244}$ which will be one comprehensive and consolidated piece of legislation. Whichever method the legislator chooses to implement reform, during the amendment of the current laws and regulations or the drafting of a new piece of legislation, it is important to keep it as simple as possible. If the laws and regulations are complex, the potential benefits may not be realised. ${ }^{245}$

Along with the new system also come new procedures that need to be followed. These new procedures need to be formally written down in legislation, explicitly stating the new criteria that are applicable to the new system. This is needed for predictability of the system and to reduce any risk of corruption that might result from vagueness. ${ }^{246}$

\section{Specific reform with regards to the CSD and e-Tender Publication Portal}

As mentioned earlier in this article, the legal documents mandating the use of the CSD and eTender Publication Portal are circulars and instruction notes issued by the National Treasury. In terms of the legal and regulatory framework making provision for e-procurement, these circulars and instruction notes, irrespective of how low in the hierarchy of law they rank, are the only sources of law mandating the CSD's and e-Tender Publication Portal's mandatory implementation.

The issuing of these circulars and instruction notes by the National Treasury is authorised by section 76 of the PFMA. This section gives the National Treasury the authority to issue circulars and instruction notes concerning any of the subjects contained in the list in section 76. It is section 76(4)(c) that authorises the National Treasury to issue circulars or instruction notes applicable to all institutions to which the PFMA applies concerning the determination of a framework for an appropriate procurement and provisioning system which is fair, equitable, transparent, competitive and cost effective.

The problem however is that the PFMA only applies to national and provincial government and not local government. The Municipal Finance Management Act 56 of 2003 ("MFMA") applies to local government. There is no equivalent to section 76 of the PFMA in the MFMA. Thus, under the MFMA, there is no express authority by which the local government is bound by the National Treasury. This makes the legal power of the circular and instruction notes

\footnotetext{
2431.

244 National Treasury 2016:59.

245 Ware, Moss, Campos \& Noone 2007:319.

246 Cohen, Mrazek \& Hawkins 2007:29 47.
} 
issued in respect of the CSD and e-Tender Publication Portal questionable. What is clear is that the National Treasury fully intends to bind local government in respect of these eprocurement technologies, as is evident from numerous media releases from the National Treasury. It is not clear how the National Treasury will make it applicable to local government.

The fact that the circulars and instruction notes issued by the National Treasury in terms of the PFMA is not binding on local government is a major flaw in the legal and regulatory framework. What is clear, if any of the benefits of the CSD and e-Tender Publication Portal, as discussed in previous sections, want to be realised, a new regulatory instrument is necessary in order to enable the National Treasury to enforce the use of these e-procurement technologies on all levels of government. This barrier to e-procurement must be removed and the only plausible way is through regulatory reform.

\section{Conclusion on reform}

The aim of a consolidated and comprehensive regulatory framework with laws specifically aimed at regulating the introduction of e-procurement is to guarantee the transparent administration of public funds by procuring entities, ${ }^{247}$ since such a substantial amount of public funds are used procuring goods and services. Only once a sound legal and regulatory framework is in place for e-procurement, will the constitutional mandate of a public procurement system that is proper and successful be achieved.

In order to reform public procurement as well as the legal and regulatory framework, sufficient support from political leadership is needed. ${ }^{248}$ Reform relies on the collaboration of various ministers and their respective departments, namely Pravin Gordhan, Minister of Finance, Thulas Nxesi, Minister of Public Works, Rob Davies, Minister of Trade and Industry, Lindiwe Zulu, Minister of Small Business Development, Siyabonga Cwele, Minister of Telecommunications and Postal Services as well as Kenneth Brown, the National Treasury's Chief Procurement Officer. ${ }^{249}$

\section{Proposed electronic public procurement system reform agenda}

When adopting an electronic public procurement system, a reform agenda is required to define the process of reform formally and to stipulate the necessary steps that need to be taken and the stages to be followed to establish an electronic public procurement system in South

\footnotetext{
247 Panayiotou, Gayialis \& Tatsiopoulos 2004:82.

248 Ware, Moss, Campos \& Noone 2007:319.

249 Minister of Finance South Africa 2016:15.
} 
Africa. ${ }^{250}$ This article proposes that the South African government, together with the National Treasury and the OCPO, devise an electronic public procurement system reform agenda, which will serve as a roadmap for procurement reform. A number of aspects that are deemed necessary for inclusion in such a reform agenda will be addressed below.

The reform agenda needs to cater to the strengths, weaknesses, degree of development and any other conditions that are specific to the South African procurement process. ${ }^{251}$ With this in mind, the role-players should firstly undertake a study to determine the type of electronic public procurement system that would be best suited for the specific characteristics of the South African public procurement regime. This would require identifying the needs of the current system. ${ }^{252}$ In the South African public procurement context, the need would be an end-to-end electronic public procurement system in terms of which the entire procurement activity will be automated and done online using ICTs. This should include a determination of the supporting infrastructure that will be necessary to support the functioning of an end-to-end electronic public procurement system dependent on ICTs, also where such infrastructure is inadequate. ${ }^{253}$ This includes digital and telecommunications infrastructure to support electronic and digital platforms and the software needed to carry out the procurement function. ${ }^{254}$ It is crucial for this information to be included in the reform agenda to ensure that the agenda is all encompassing of all the information needed to set the reform in motion.

The reform agenda should then address the budgeting and planning aspects of creating an e-procurement system tailored for South African public procurement. A costbenefit analysis should also be undertaken on the cost of developing such a system, the cost of the infrastructure that needs to be developed and the cost of training procurement staff.

Once the identification of the needs, budgeting and planning aspects are dealt with, the selection or award process for the goods, services and works that will be needed for the reform should be defined as well as the management of the contracts and the payment systems. ${ }^{255}$ Thereafter, the call can be made for bids or quotes for the technology and infrastructure that will be needed. ${ }^{256}$ Awarding the contract to the best bidder and the signing of the contract should follow in accordance with the selection process set out in the reform agenda itself. The next stage will be the execution of the contract in terms of which the digital and

250 The Chilean government developed an information technology strategic plan to guide the public sector modernisation process. An electronic public procurement reform agenda that is proposed for the South African government will serve the same purpose; Asian Development Bank, 2004:1. 251 Asian Development Bank, 2004:1.

2524.

253 Williams-Elegbe 2014:215.

254215.

255 UNCITRAL, 2014:27.

${ }^{256}$ Asian Development Bank, 2004:4. 
telecommunications infrastructure will be erected and the technology and software developed. ${ }^{257}$ The e-procurement system will then be implemented. The most effective method of implementation of a new e-procurement system has been in a staged manner. If this method is followed, it can assist in gradually writing off the initial investment costs. ${ }^{258}$

In the paragraphs to follow certain aspects will be highlighted that should be taken into consideration when drafting the reform agenda. These aspects pertain to integral functionalities of an e-procurement system. As regards the operation of an e-procurement system, it is of the utmost importance that the public has confidence in the security of the new system so that suppliers will be willing to use it. ${ }^{259}$ Thus, when it comes to the design of the eprocurement system, sufficient care must be taken to ensure high levels of confidentiality, accountability and transparency. To ensure this, certain safeguards are necessary. These safeguards require the adequate authentication of suppliers, sufficiently reliable technology, a system that does not compromise tenders or any other submissions, as well as adequate security to ensure that confidential supplier information remain confidential, cannot be accessed by competitors and is not misused in any way. ${ }^{260}$ It is also necessary for the system to provide adequate protection against unauthorised actions aimed at disrupting the normal operation of the public procurement process. ${ }^{261}$ By including electronic signature technology that can legally warrant the authenticity and integrity of the content of electronic documents available in online tenders, can support the confidentiality and accountability of the system. ${ }^{262}$ It would ensure that electronic documents and communications are traceable to the supplier who submitted it. ${ }^{263}$

An e-procurement system can automate numerous elements of the examination and evaluation processes of tenders. The automation of these processes can save time; costs and it can reduce the administrative burden for the procuring entity. ${ }^{264}$ The e-procurement system should thus be equipped with the tools needed to examine and evaluate the tenders received from the suppliers. Not only will this improve the efficiency of the procurement process, it will also enhance transparency during the evaluation phase seeing as human error and interference is eliminated. ${ }^{265}$ The automation of these processes will also expedite the

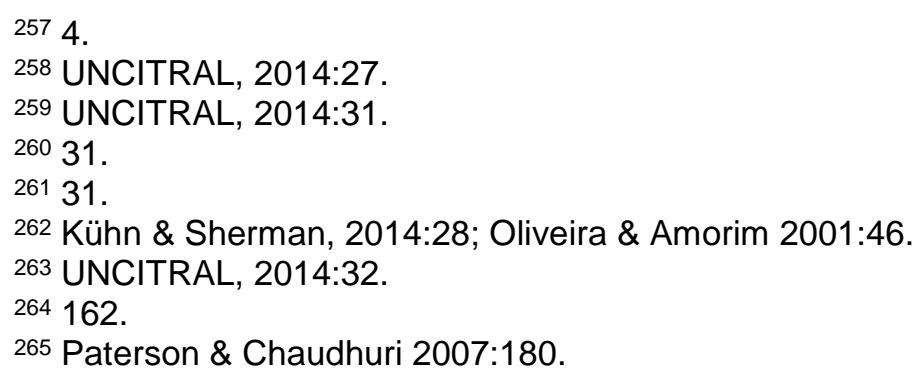


evaluation and adjudication processes leading to the award of bids. ${ }^{266}$ This will be the case seeing as it will no longer be required to establish and select the members of a bid evaluation committee and a bid adjudication committee to evaluate the bids received and make the final award of the bid because the evaluation and adjudication processes of the bids will be automated. ${ }^{267}$

An e-procurement system should be able to deal with complex equations when evaluating bids, since the lowest price is not the prevailing criterion in the South African public procurement system. The system should accordingly be able to deal with a number of variables, which includes price as well as preference when evaluating a bid. ${ }^{268}$

Computerisation in the procurement process can help process evaluation results and generate evaluation reports. The use of a computerised registry of suppliers improves the integrity of the prequalification process. For instance, the legal, commercial and financial data of suppliers in the database can be compared with the qualifications needed for a specific government contract. A list of eligible suppliers can then be generated, together with a list of suppliers not qualifying and the reasons for their disqualification. ${ }^{269}$

Most importantly, the reform agenda should also address the revision of the legal and regulatory framework governing public procurement, namely what laws and regulations can be kept, what laws and regulations should be amended and what laws and regulations need to be deleted and new ones drafted for.

Only once the entire reform agenda has received approval, should the design of the system commence.

\section{Conclusion}

The time is ripe for the South African government to transition from a traditional paper-based public procurement system to an electronic public procurement system using ICTs. Implemented correctly, with a sound reform agenda in place, as well as a proper legal and regulatory framework to support an end-to-end e-procurement system, an electronic public procurement system can achieve certain objectives for both government and suppliers. The

\footnotetext{
266 Ntingi, 2014.

267 Regulation 16A6.2(a), (b) and (c) of the Treasury Regulations issued in terms of the Public Finance Management Act 1 of 1999 (PFMA); National Treasury South Africa 2004:3-4.

268 Oliveira \& Amorim 2001:45.

269 Paterson \& Chaudhuri 2007:180.
} 
most noteworthy being a reduction in corruption, improved transparency, savings in cost and advantages for suppliers.

A reform of the current South African public procurement system is already underway. The modernisation of the public procurement system was set in motion with the recent implementation of the CSD and the e-Tender Publication Portal. In so doing, the National Treasury has taken the first steps towards transforming the South African public procurement system from a traditional paper-based one to an electronic one. Although the CSD and eTender Publication Portal are merely the entry technologies needed to support an eprocurement platform, a number of benefits have already materialised through their use. The most noteworthy being governance, effectiveness and balanced development. Governance is possible seeing as potential suppliers, the public, civil society and the government itself can monitor the procurement process from anywhere at any time because the procurement process can be viewed online as they take place. This in turn promotes transparency and accountability. It will also act as an incentive for new suppliers, which will encourage competition. ${ }^{270}$ Efficiency is achievable through the standardisation, streamlining and integration of the procurement process. This in turn can result in savings in costs and a reduction in processing times due to the increased efficiency with which procurement is being done. ${ }^{271}$ Balanced development is achieved through increased levels of productivity and competition, the facilitation of the development of SMMEs and economic decentralisation. ${ }^{272}$

Collectively, these solutions have been able to eliminate the barriers to do business with Government by reducing the red tape as well as simplifying the procurement process. The CSD and the e-Tender Publication Portal will significantly reduce the administrative burden for Government and business alike, while enhancing the monitoring of prices and procurement patterns.

It seems as though the current approach taken by the National Treasury together with the OCPO with regards to the reform of the public procurement system, is to apply eprocurement technologies such as the CSD and the e-Tender Publication Portal to existing public procurement measures. The risk of implementing one e-procurement technology at a time to an existing process is that it can lead to the e-procurement system becoming haphazard. It is suggested that reform should rather take place by completely restructuring the procurement process around the technical capabilities of new technologies. Reform should entail the design, development and implementation of an entirely new electronic public

270 Asian Development Bank, 2004:5.

2715.

2726. 
procurement system that provides a suitable and reliable platform for procurement to be done electronically.

Successful reform is threatened by a number of challenges in respect of transitioning to an electronic public procurement platform. The problems anticipated to pose the biggest threat to successful reform are the technology required for the effective implementation and functioning of such a system, the inexperience of government procurement officials, the possible retrenchment of superfluous procurement staff and the overall expense of a new eprocurement system. If these challenges are not addressed properly, it can have a potential negative impact on the performance of the procurement function and the quality of delivery. ${ }^{273}$ The advantages of using ICT in public procurement can only be realised if these weaknesses or problems are addressed adequately.

Reform of the South African public procurement system can be achieved and most of these weaknesses overcome by adopting an electronic public procurement plan that sets out the detailed steps that need to be taken in order to fully transition from a paper-based procurement system to an end-to-end e-procurement system. This will however require a legal and regulatory framework to support the use of e-procurement since procurement is highly regulated in the South African regime. At this moment in time, the legal landscape is not properly able to facilitate the use of electronic public procurement. Reform of the legal and regulatory framework governing the South African public procurement system is necessary to ensure compliance between an electronic public procurement system and the legal framework. ${ }^{274}$ To ensure this compliance, it may be necessary to amend the current laws and regulations or to draft provisions regulating e-procurement a new. With supporting structures such as a reform agenda and a comprehensive legal and regulatory framework in place to anchor an e-procurement system, e-procurement can be a tool to reform the South African public procurement system.

Electronic public procurement is a promising innovation and can be an effective tool to reform public procurement in the South African context. It can potentially lead to a public procurement system that is more fair and effective. The establishment of an electronic public procurement system will not only be to the advantage of government and businesses alike, but also to every tax paying South African citizen. An e-procurement system can save the taxpayer significant sums of money since, in the end, it is public funds that are used to finance the procurement activity.

\footnotetext{
273 De la Harpe 2015:1588.

274 Oliveira \& Amorim 2001:46.
} 


\section{Bibliography}

16 ${ }^{\text {th }}$ Bled Electronic Commerce Conference: eTransformation, 2005. eProcurement: Challenges and Opportunities. Bled Electronic Commerce Conference. Available at: $<$ https://domino.fov.uni-

mb.si/proceedings.nsf/Proceedings/D156F5E971437925C1256EA200317A65/\$File/13Tsch am.pdf> [Accessed 19-09-2016].

Akamai, 2016. Akamai's State of the Internet Report: Q1 2016. Akamai, [online]. Available at: $<$ https://www.akamai.com/us/en/multimedia/documents/state-of-the-internet/akamai-state-ofthe-internet-report-q1-2016.pdf> [Accessed 21-09-2016].

Ambe, IM. \& Badenhorst-Weiss, JA. 2012. Procurement Challenges in the South African Public Sector. Journal of Transport and Supply Chain Management 6:242.

Arrowsmith, S. 2004. Public Procurement: An Appraisal of the UNCITRAL Model Law as a Global Standard. International and Comparative Law Quarterly 53:17.

Asian Development Bank, 2013. e-Government Procurement Handbook. Asian Development Bank, [online]. Available at: <http://www.adb.org/sites/default/files/institutionaldocument/34064/files/e-government-procurement-handbook.pdf> [Accessed 01-09-2016].

Asian Development Bank, 2004. Electronic Government Procurement Roadmap. The World Bank, [online]. Available at: $<$ http://siteresources.worldbank.org/INFORMATIONANDCOMMUNICATIONANDTECHNOL OGIES/Resources/eGPRoadMap.pdf> [Accessed 12-08-2016].

Auditor-General South Africa, 2015. Consolidated General Report on the National and Provincial Audit Outcomes 2014-15. Auditor-General South Africa, [online]. Available at: <https://www.agsa.co.za/Documents/Auditreports/PFMA20142015.aspx> [Accessed 02-082016].

Bolton, P. 2008. Protecting the Environment through Public Procurement: The Case of South Africa. Natural Resource Forum 32:1.

Caborn, E. \& Arrowsmith, S. 2012. Procurement Methods in the Public Procurement Systems of Africa. In Arrowsmith, S. \& Quinot, G. (Eds). Public Procurement Regulation in Africa. Cambridge: Cambridge University Press. 
Campos, JE., Pradhan, S. \& Recanatini, F. 2007. Conclusion: Where to Next?. In Campos, JE. \& Pradhan, S. (Eds.). The Many Faces of Corruption: Tracking Vulnerabilities at the Sector Level. Washington D.C.: World Bank.

Cohen, JC., Mrazek, MF. \& Hawkins, L. Corruption and Pharmaceuticals: Strengthening Good Governance to Improve Access. In Campos, JE. \& Pradhan, S. (Eds.). The Many Faces of Corruption: Tracking Vulnerabilities at the Sector Level. Washington D.C.: World Bank.

De la Harpe, S. 2015. Procurement under the UNCITRAL Model Law: A Southern Africa Perspective. Potchefstroom Electronic Law Journal 18:1572.

Eskom, 2015. What is Load Shedding?. Eskom, [online]. Available at: <http://loadshedding.eskom.co.za/loadshedding/description> [Accessed 14-09-2016].

Henriksen, HZ. \& Mahnke, V. 2005. E-Procurement Adoption in the Danish Public Sector. Scandinavian Journal of Information Systems 17:85.

Jooste, MV. \& Van Schoor, CdeW. 2003. A Framework for the Implementation of Eprocurement. South African Journal of Industrial Engineering 14:1.

Kühn, S. \& Sherman, LB. 2014. Curbing Corruption in Public Procurement: A Practical Guide. Transparency International, [online]. Available at: $<$ https://issuu.com/transparencyinternational/docs/2014_anticorruption_publicprocureme?e= 2496456/8718192> [Accessed 11-04-2016].

Lebone, K. 2016. South Africa Survey 2016: Communications. South African Institute of Race Relations, [online] 25 April. Available at: <http://irr.org.za/reports-and-publications/southafrica-survey/south-africa-survey-2016/downloads/communications> [Accessed 22-09-2016].

Liao, TS., Wang, MT. \& Tserng, HP. 2002. A Framework of Electronic Tendering for Government Procurement: A Lesson Learned in Taiwan. Automation In Construction 11:731.

MacManus, SA. 2002. Understanding the Incremental Nature of E-procurement Implementation at the State and Local Levels. Journal of Public Procurement 2:5.

National Treasury South Africa, 2015. 2015 Public Sector Supply Chain Management Review. South African Government, [online]. Available at:

<http://www.gov.za/sites/www.gov.za/files/supplychainmanagementreview_.pdf> [Accessed 16-06-2016].

National Treasury South Africa, 2015. About eTenderPublication. eTenderPublication, [online]. Available at: <http://www.etenders.gov.za/content/about-etenderpublication> [Accessed 12-06-2016]. 
National Treasury South Africa, 2015. Annexure 1: Factsheet on eTender Publication Portal for Government. South African Government, [online] 4 August. Available at: <http://www.gov.za/sites/www.gov.za/files/speech_docs/Annexure1\%20eTender\%20\%282\% 29.pdf> [Accessed 11-04-2016].

National Treasury South Africa, 2015. Annexure 2: Factsheet on Central Supplier Database for Government. South African Government, [online] 4 August. Available at: <http://www.gov.za/sites/www.gov.za/files/speech_docs/Annexure2\%20CSD.pdf> [Accessed 13-04-2016].

National Treasury South Africa, 2002. General Procurement Guidelines. National Treasury, [online]. Available

at: <http://www.treasury.gov.za/divisions/ocpo/sc/Guidelines/GENERAL\%20PROCUREMENT\% 20GUIDELINES\%20-\%202.pdf> [Accessed 17-03-2016].

National Treasury South Africa, 2015. Home. Central Supplier Database for Government, [online]. Available at: <https://secure.csd.gov.za/> [Accessed 02-04-2016].

National Treasury South Africa, 2015. Home. eTenderPublication, [online]. Available at: <http://www.etenders.gov.za/> [Accessed 06-04-2016].

National Treasury South Africa, 2016. SCM Review Update - 2016. National Treasury, [online]. Available at: <http://www.treasury.gov.za/publications/other/SCM\%20Review\%20Update\%202016.pdf> [Accessed 04-09-2016].

National Treasury South Africa, 2015. Treasury Launches Central Supplier Database and eTender Publication Portal. South African Government, [online] 4 August. Available at: $<$ http://www.gov.za/speeches/launching-central-supplier-database-and-etender-publicationportal-8-apr-2015-0000> [Accessed 06-04-2016].

Ntingi, A. 2014. Brown Hunting for E-procurement System to Curb Wastage. GetBiz, [online] 3 October. Available at: <http://www.getbiz.co.za/index.php/biz-news/business-andeconomy/77-brown-hunting-for-e-procurement-system-to-curb-wastage $>$ [Accessed 02-082016].

Oliveira, LMS. \& Amorim, PP. 2001. Public E-procurement. International Financial Law Review 20:43.

Panayiotou, NA., Gayialis, SP. \& Tatsiopoulos, IP. 2004. An E-procurement System for Governmental Purchasing. International Journal of Production Economics 90:79. 
Paterson, WDO. \& Chaudhuri, P. 2007. Making Inroads on Corruption in the Transport Sector through Control and Prevention. In Campos, JE. \& Pradhan, S. (Eds.). The Many Faces of Corruption: Tracking Vulnerabilities at the Sector Level. Washington D.C.: World Bank.

Roche, J. 2001. Are You Ready for E-procurement?. Strategic Finance 83:56.

Schoenherr, T. \& Rao Tummala, VM. 2007. Electronic Procurement: A Structured Literature Review and Directions for Future Research. International Journal of Procurement Management 1:8.

South African Government News Agency, 2015. e-Tender Publication Portal Launched. SAnews.gov.za, [online] 9 April. Available at: <http://www.sanews.gov.za/south-africa/etender-publication-portal-launched> [Accessed 02-04-2016].

Stalzer, J. 2015. Challenges and Opportunities of e-Procurement. Schoenherr Roadmap 15, [online]. Available at: <http://roadmap2015.schoenherr.eu/challenges-opportunities-eprocurement/> [Accessed 11-09-2016].

STANLIB, 2015. Internet Access, Speed and Cost: South Africa is Improving but Remains Well behind the Global Standard Meaning We Are Missing Out on Growth Opportunities. STANLIB, [online]. Available at:

<http://www.stanlib.com/EconomicFocus/Pages/Internetaccessspeedrsa.aspx> [Accessed 21-09-2016].

Timm, S. 2016. Budget Shows SA Getting More Serious About SMEs. Small Business Insight, [online] 26 February. Available <http://www.smallbusinessinsight.org/blog/category/procurement> [Accessed 13-04-2016].

Timm, S. 2016. E-procurement Portal Will Boost SMEs. Fin24, [online] 12 March. Available at: $\quad$ <http://www.fin24.com/Entrepreneurs/News/E-procurement-portal-will-boost-SMEs20150312> [Accessed 28-03-2016].

Ware, GT., Moss, S., Campos, JE. \& Noone, GP. 2007. Corruption in Public Procurement: A Perennial Challenge. In Campos, JE. \& Pradhan, S. (Eds.). The Many Faces of Corruption: Tracking Vulnerabilities at the Sector Level. Washington D.C.: World Bank.

UNCITRAL, 2014. Guide to Enactment of the UNCITRAL Model Law on Public Procurement. UNCITRAL, [online]. Available at: <http://www.uncitral.org/pdf/english/texts/procurem/mlprocurement-2011/Guide-Enactment-Model-Law-Public-Procurement-e.pdf> [Accessed 0609-2016].

United Nations Office on Drugs and Crime, 2013. Guidebook on Anti-Corruption in Public Procurement and the Management of Public Finances. United Nations Office on Drugs and 
Crime,

[online].

Available

at:

<http://www.unodc.org/documents/corruption/Publications/2013/Guidebook_on_anti-

corruption_public_procurement_and_the_management_of_public_finances.pdf> [Accessed 11-04-2016].

Williams-Elegbe, S. 2014. Beyond UNCITRAL: The Challenges of Procurement Reform Implementation in Africa. Stellenbosch Law Review 1:209.

\section{$\underline{\text { Constitution }}$}

The Constitution of the Republic of South Africa, 1996.

Legislation

Municipal Finance Management Act 56 of 2003.

Public Finance Management Act 1 of 1999.

$\underline{\text { Circulars }}$

National Treasury South Africa Central Supplier Database Circular No: 3 of 2015/2016.

National Treasury South Africa Implementation of Supply Chain Management Circular of 2004 3-4.

\section{$\underline{\text { Instruction notes }}$}

National Treasury South Africa Advertisements of Bids and the Publication of Awards on the e-Tender Publication Portal Instruction Note No: 1 of 2015/2016.

National Treasury South Africa Central Supplier Database Instruction Note No: 4A of $2016 / 2017$.

\section{Official publications}

Minister of Finance South Africa 2015 Budget Speech Report No: 10 of 2015.

Minister of Finance South Africa 2016 Budget Speech Report No: 17 of 2016.

National Treasury Budget Review 2015 Report No: 9 of 2015.

National Treasury Budget Review 2016 Report No: 16 of 2016. 